\title{
PERSEPSI DAN PARTISIPASI MASYARAKAT TERHADAP PENGELOLAAN SAMPAH RUMAH TANGGA MELALUI BANK SAMPAH DI JAKARTA SELATAN
}

\section{Perception and Participation on the Household Waste Management through in South Jakarta}

\author{
Aditya Nugraha ${ }^{\mathrm{a}}$, Surjono H. Sutjahjo ${ }^{\mathrm{b}}$, Akhmad Arif Amin ${ }^{\mathrm{c}}$ \\ ${ }^{a}$ Program Studi Pengelolaan Sumberdaya Alam dan Lingkungan Sekolah Pascasarjana, Institut Pertanian Bogor, \\ Kampus IPB Baranangsiang, Bogor 16143 - aditya.aktivis@gmail.com \\ ${ }^{b}$ Departemen Agronomi dan Hortikultura, FakultasPertanian, Institut Pertanian Bogor, Kampus IPB Darmaga, \\ Bogor 16680 \\ ${ }^{c}$ Departemen Ilmu Penyakit Hewan dan Kesehatan Masyarakat Veteriner (IPHK), Fakultas Kedokteran Hewan, \\ Institut Pertanian Bogor, Kampus IPB Darmaga, Bogor 16680
}

\begin{abstract}
Population growth and changes in consumption pattern have increased the municipal waste volume in DKI Jakarta. Waste management issue has been more formidable after the government has failed to overcome the situation with sufficient waste management facilities. Hence, society's active participation is needed to create a more comprehensive system of municipal waste management, based on "reduce, reuse, recycle" principle. The objective of this study is to (1) identify the community perception and participation in the household waste management, (2) analyze the correlation between the internal and external factors of individual with the perception on the household waste management, and (3) analyze the correlation between community perception and participation in household waste management. The observed variables are divided into two factors, namely internal factors and external factors. The data were collected using survey method by distributing questionnaire, while Chi Square Test and Spearman Rank Correlation Test were used for data processing. The results showed that respondents have positive perception and high participation in the household waste management. There is a significant correlation between the internal and external factors of individual with community perception on the household waste management. Community perception on household waste management is also significantly correlated to community participation in household waste management.
\end{abstract}

Keywords: Bank sampah, partisipasi, pengelolaan sampah rumah tangga, persepsi, prinsip 3R

(Diterima: 23-05-2017; Disetujui: 18-09-2017)

\section{Pendahuluan}

Undang-undang Nomor 18 Tahun 2008 menyebutkan bahwa definisi sampah sebagai sisa kegiatan sehari-hari manusia dan/atau proses alam yang berbentuk padat, sedangkan pengelolaan sampah merupakan kegiatan yang sistematis, menyeluruh, dan berkesinambungan yang meliputi pengurangan dan penanganan sampah. Saat ini hampir semua negara berkembang memiliki permasalahan dalam pengelolaan sampah (Dortman, 2015) termasuk di Indonesia.

Masalah sampah di DKI Jakarta merupakan masalah yang selalu hangat dibicarakan, karena DKI Jakarta merupakan ibukota negara indonesia dengan jumlah penduduk padat dan mengalami pertambahan penduduk dari tahun ke tahun.

Timbulan sampah padat kota dari tahun ke tahun terus meningkat, pada tahun 2011 sampah yang dihasilkan di wilayah DKI Jakarta sebanyak 5,597.87 ton/hari dengan sampah terangkut 4,986.31 ton/hari dan sampah yang tidak terangkut 611.56 ton/hari, pada tahun 2012 sampah yang dihasilkan di wilayah DKI Jakarta sebanyak 6,356.88 ton/hari dengan sampah terangkut 6,004.2 ton/hari dan sampah yang tidak terangkut 352.68 ton/hari, pada tahun 2013 sampah yang dihasilkan di wilayah DKI Jakarta sebanyak 6,513.85 ton/hari dengan sampah terangkut 5,636.90 ton/hari dan sampah yang tidak terangkut 876.95 ton/hari (Dinas Kebersihan Prov. DKI Jakarta), padahal secara umum penanganan sampah di DKI Jakarta sudah mulai menggunakan pendekatan penanganan sampah langsung di sumbernya.

Kementerian Lingkungan Hidup dan Kehutanan (KLHK) menyebutkan bahwa jumlah timbulan sampah di Indonesia telah mencapai 175.000 ton/hari atau setara 64 juta ton/tahun dengan pengelolaan sebagai berikut diangkut dan ditimbun di TPA sebanyak 69\%, dikubur $10 \%$, dikompos dan didaur ulang 7\%, dibakar $5 \%$, dan sisanya tidak terkelola $7 \%$. Mengacu pada data tersebut terlihat saat ini pengelolaan sampah masih terkonsentrasi di Tempat Pemrosesan Akhir (TPA) sampah tanpa melalui proses 3R (reduce, recycle, reuse) di sumber dengan melibatkan partisipasi masyarakat. Kondisi ini menjadi faktor utama beban TPA menjadi berat dan umur penggunaannya semakin pendek (Suyanto et al., 2015).

Berdasarkan komposisinya maka sampah terbagi menjadi jenis sampah organik $60 \%$, plastik $15 \%$, kertas 10\%, dan logam, kaca, kain, kulit 15\% (KLHK, 2015). Sampah organik didominasi oleh sampah makanan (produk hewani dan nabati), sayur-sayuran, buah- 
buahan, limbah ikan, limbah pertanian dan perkebunan, limbah kayu, daun-daunan, ranting, serta kotoran hewan dan manusia. Sampah organik tersebut apabila tidak ditangani dengan baik dapat menjadi sumber penyebab penyakit, menimbulkan bau busuk, mengganggu nilai estetika kota, dan mencerminkan ketidakpedulian pemerintah dan masyarakat akan kebersihan dan kesehatan lingkungan. Selain itu, dapat menjadi sumber pencemar yang menghasilkan limbah cairan lindi mencemari air tanah dan gas metan mencemari udara penyebab pemanasan global.

Pola pengelolaan sampah dengan melibatkan masyarakat sebagai aktor yang dapat berperan aktif dalam mengurangi volume sampah merupakan keputusan yang tepat dalam mengantisipasi peningkatan jumlah volume sampah perkotaan yang terus meningkat akibat peningkatan jumlah penduduk. Peran aktif masyarakat atau individu dapat dimulai dengan melaksanakan perilaku positif dalam mengelola sampah seperti pengumpulan, pewadahan, pemilahan dan melakukan daur ulang sampah untuk mengurangi volume dan persebaran sampah.

Partisipasi masyarakat adalah keterlibatan masyarakat dalam menentukan arah, strategi dalam kebijakan kegiatan, memikul beban dalam pelaksanaan kegiatan, dan memetik hasil dan manfaat kegiatan secara merata. Partisipasi juga berarti memberi sumbangan dan turut serta menentukan arah atau tujuan yang akan dicapai, yang lebih ditekankan pada hak dan kewajiban bagi setiap orang (Manurung, 2008). Koentjaraningrat (1991) berpendapat bahwa partisipasi berarti memberi sumbangan dan turut serta menentukan arah dan tujuan pembangunan, yang ditekankan bahwa partisipasi adalah hak dan kewajiban bagi setiap masyarakat.

Partisipasi masyarakat dalam konteks pengelolaan sampah dapat berupa pemilahan antara sampah organik dan sampah anorganik dalam proses pewadahan, atau melalui pembuatan kompos dalam skala keluarga dan mengurangi penggunaan barang yang tidak mudah terurai (Yolarita, 2011). Candra (2012) mengungkapkan bahwa konsep partisipasi dapat diukur melalui tahap perencanaan, tahap pelaksanaan, dan tahap pemanfaatan. Bila dikaitkan dengan pengelolaan sampah, maka partisipasi masyarakat dalam pengelolaan sampah tidak hanya dilihat dari ikut sertanya masyarakat dalam proses pelaksanaan mengelola sampah, tetapi juga ikut serta menjadi anggota organisasi yang berkaitan dengan masalah sampah yang berperan dalam merencanakan sistem pengelolaan sampah yang baik.

Yuliastuti et al. (2013) menambahkan bahwa partisipasi masyarakat dalam pengelolaan sampah dapat berupa partisipasi secara tidak langsung. Yang dimaksud dengan partisipasi tidak langsung ini adalah keterlibatan masyarakat dalam masalah keuangan, yaitu partisipasi dalam pengelolaan sampah dengan cara melakukan pembayaran retribusi pelayanan persampahan melalui dinas terkait yang secara langsung memberikan pelayanan dalam kebersihan. Dalam penelitian Manurung (2008), salah satu bentuk partisipasi terhadap pengelolaan sampah juga dapat dilihat dari kesediaan membayar (willingness to pay) untuk peningkatan fasilitas pengelolaan sampah agar kebersihan dan kualitas lingkungan tetap terjaga.

Alfiandra (2009) menjelaskan bahwa partisipasi masyarakat sering diartikan sebagai keikutsertaan, keterlibatan dan kesamaan anggota masyarakat dalam suatu kegiatan tertentu baik secara langsung maupun tidak langsung, sejak dari gagasan, perumusan kebijakan, pelaksanaan program dan evaluasi. Partisipasi secara langsung berarti anggota masyarakat ikut memberikan bantuan tenaga dalam kegiatan yang dilaksanakan, sedangkan partisipasi tidak langsung dapat berupa sumbangan pemikiran, pendanaan, dan material yang diperlukan. Menurut Walgito (1999) dalam Alfiandra (2009), partisipasi masyarakat memiliki hubungan yang erat antara individu satu dengan individu yang lain atau sebaliknya, terdapat hubungan yang bersifat timbal balik dan saling mempengaruhi. Hubungan tersebut terdapat di antara individu dengan individu, individu dengan kelompok atau kelompok dengan kelompok. Pada umumnya, dapat dikatakan bahwa tanpa partisipasi masyarakat maka setiap kegiatan pembangunan akan kurang berhasil.

Persepsi merupakan salah satu aspek psikologis yang penting bagi manusia dalam merespon kehadiran berbagai aspek dan gejala di sekitarnya. Persepsi mengandung pengertian yang sangat luas. Berbagai ahli telah memberikan definisi yang beragam tentang persepsi, walaupun pada prinsipnya mengandung makna yang sama. Menurut Kamus Besar Bahasa Indonesia (2005), persepsi adalah tanggapan (penerimaan) langsung dari sesuatu dan merupakan proses seseorang mengetahui beberapa hal melalui panca inderanya.

Program Bank Sampah merupakan salah satu pengelolaan sampah berbasis masyarakat, yang merupakan konsep pengelolaan sampah mengintegrasikan prinsip 3R yaitu reduce, reuse dan recycle dengan pengelolaan sedekat mungkin dengan sumbernya. Reduce adalah mengurangi timbulan sampah pada sumbernya. Reuse merupakan upaya pemanfaatan kembali sampah atau barang yang tidak berguna lagi, sedangkan recycle adalah pendaurulangan sampah menjadi barang lain yang bernilai ekonomis.

Kegiatan dari sistem Bank Sampah adalah dilakukan dari, oleh dan untuk masyarakat. Seperti bank konvensional pada umumnya, Bank sampah memiliki sistem manajerial yang operasionalnya dilakukan sendiri oleh masyarakat.

Penelitian ini bertujuan mengkaji persepsi dan partisipasi masyarakat (nasabah) bank sampah rawajati terhadap pengelolaan sampah rumah tangga serta mengindentifikasi hubungan antara faktor internal dan eksternal individu dengan persepsi terhadap pengelolaan sampah rumah tangga serta menganalisis hubungan antara persepsi dan partisipasi masyarakat dalam pengelolaan sampah rumah tangga. 


\section{Material dan Metode}

\subsection{Lokasi dan Waktu Penelitian}

Penelitian dilakukan di Bank Sampah Rawajati, Pancoran, Jakarta Selatan pada bulan januari sampai februari 2015.

\subsection{Alat dan Bahan}

Peralatan yang digunakan dalam penelitian ini dintaranya : kuisioner, kamera, software analisis data SPSS for Windows versi 20.0

\subsection{Metode}

\subsubsection{Pengumpulan Data}

Tahapan dalam penelitian ini meliputi kegiatan pengumpulan data pada bank sampah Rawajati, Pancoran, Jakarta Selatan, analisis perilaku sosial dan persepsi masyarakat (dengan menggunakan software SPSS. Adapun variabel yang diamati dibagi menjadi dua faktor, yaitu faktor internal (usia, jenis kelamin, tingkat pendidikan, pekerjaan, pendapatan, pengetahuan responden dalam pengelolaan sampah rumah tangga dan pengalaman responden dalam pengelolaan sampah rumah tangga) serta faktor eksternal (peran pemerintah dan sarana prasarana).

\subsubsection{Analisis Data}

Dilakukan dengan metode survey menggunakan kuesioner dan pengolahan data menggunakan Uji Chi Square dan Uji Korelasi Rank Spearman. Uji korelasi Chi Square digunakan untuk mengetahui hubungan antara dua variabel yang berskala nominal.

Uji korelasi Rank Spearman digunakan untuk mengetahui ada atau tidaknya hubungan antar dua variabel yang berskala ordinal dan tidak menentukan prasyarat data terdistribusi normal. Selain analisis data kuantitatif, dilakukan pula analisis data kualitatif sebagai pendukung data kuantitatif. Data kualitatif akan diolah melalui tiga tahap analisis data kualitatif, yaitu reduksi data, penyajian data dan penarikan kesimpulan. Analisis data kualitatif diuraikan secara deskriptif sebagai pendukung data kuantitatif. Uji Rank Spearman pada taraf kepercayaan 95\% ( $<<0.05)$. Data diolah menggunakan program software SPSS.

\section{Hasil dan Pembahasan}

\subsection{Bank Sampah Rawajati}

Bank sampah rawajati berdiri di RW 03 Kelurahan Rawajati, Kecamatan Pancoran, Kota Jakarta Selatan. Secara geografis, RW 03 Kelurahan Rawajati berbatasan dengan wilayah - wilayah lainnya. Batasbatas wilayah RW 03 Kelurahan Rawajati adalah sebagai berikut. 1. Sebelah utara, berbatasan dengan wilayah RW 01 (pemukiman umum). 2. Sebelah selatan, berbatasan dengan wilayah RW 06 (perumahan kalibata indah). 3. Sebelah timur, berbatasan dengan sungai ciliwung. 4. Sebelah barat, berbatasan dengan wilayah RW 02 (pemukiman umum). Berikut gambar denah RW 03 Kelurahan Rawajati

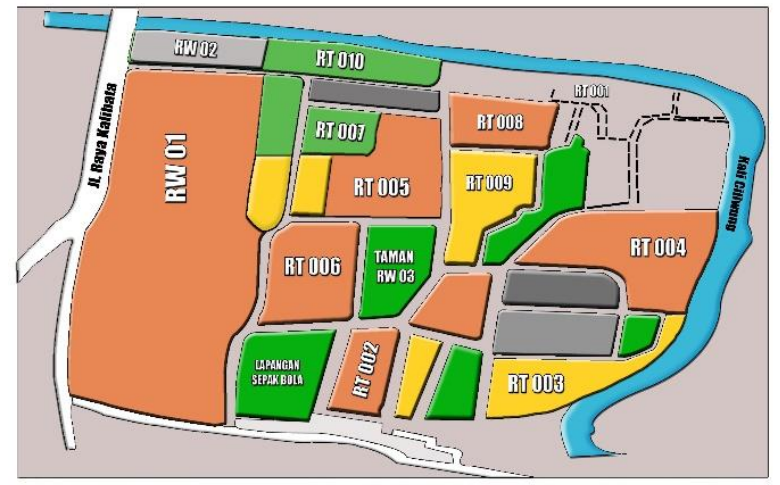

Gambar 1. Denah lokasi RW 03 Kel. Rawajati, Kec. Pancoran

Kelurahan Rawajati memiliki bank sampah percontohan yang terletak di RW 03. Bank sampah tersebut bernama Bank Sampah Rawajati. Pendirian bank sampah ini dilakukan secara swadaya oleh masyarakat RW 03. Penelitian ini lebih memusatkan perhatian kepada masyarakat di daerah RW 03 karena di lokasi tersebut merupakan daerah percontohan mengenai pengelolaan sampah rumah tangga.

Pengolahan sampah organik yang dilakukan di bank sampah rawajati adalah teknik pengomposan dan biopori. Teknik pengomposan yaitu proses perombakan (dekomposisi) dan stabilisasi bahan organik oleh mikro organisme dalam keadaan lingkungan yang terkontrol dengan hasil akhir berupa humus dan kompos (Simamora et al., 2006). Pengomposan adalah system pengolahan sampah organik dengan bantuan mikro organisme sehingga terbentuk pupuk organik yang lebih dikenal dengan pupuk kompos yang mengandung materi yang kaya unsur hara, antara lain nitrogen, fosfor dan kalium yang baik untuk pupuk tanaman.

Pengolahan sampah anorganik yang berada di masyarakat, dipilah dan dikumpulkan masing - masing nasabah bank sampah untuk kemudian disetorkan pada waktu yang telah ditentukan ke bank sampah rawajati. Sampah anorganik yang telah terpilah dan terkumpul di bank sampah kemudian dikelola oleh bank sampah untuk di jual dan di daur ulang kembali seperti terlihat pada Gambar 3. 


\section{MANAJEMEN SAMPAH TPST JATIMAS}

RW 03 - RAWAJATI

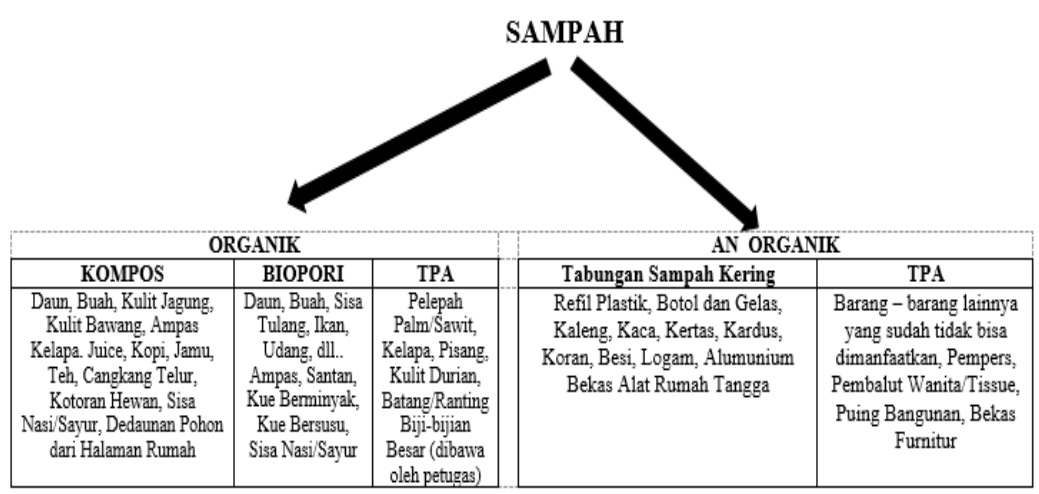

JADWAL PENGAMBILAN SAMPAH

RW 03 RAWAJATI PANCORAN JAKARTA SELATAN

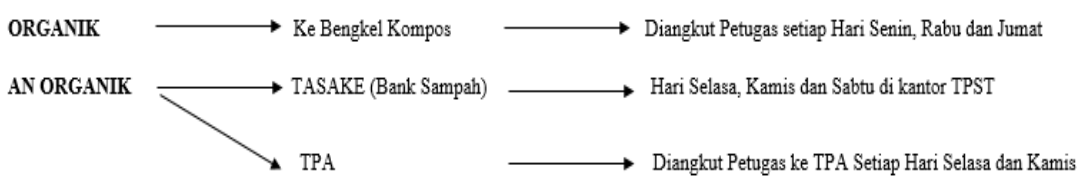

BAGI WARGA YANG TIDAK MEMILAH, SAMPAH TIDAK DIAMBIL OLEH PETUGAS !!!

Gambar 2. Manajemen sampah dan jadwal pengambilan sampah

\subsection{Persepsi dan Partisipasi Masyarakat Terhadap Pengelolaan Sampah Rumah Tangga}

Sugihartono et al. (2007) mengemukakan bahwa persepsi adalah kemampuan otak dalam menerjemahkan stimulus yang masuk ke dalam alat indera manusia. Dalam persepsi manusia, terdapat perbedaan sudut pandang dalam penginderaan. Ada yang mempersepsikan sesuatu itu baik atau buruk. Persepsi positif maupun persepsi negatif akan mempengaruhi tindakan manusia yang tampak atau nyata. Selanjutnya mengenai partisipasi, Alfiandra (2009) menjelaskan bahwa partisipasi masyarakat diartikan sebagai keikutsertaan, keterlibatan dan kesamaan anggota masyarakat dalam suatu kegiatan tertentu baik secara langsung maupun tidak langsung.

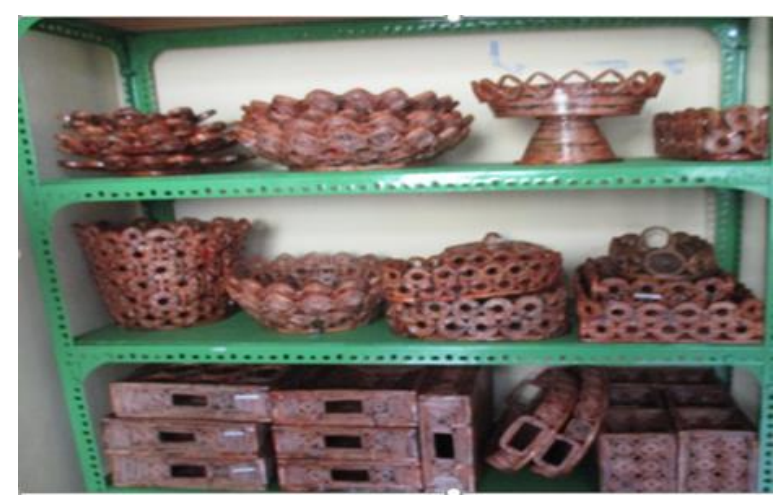

Gambar 3. Hasil daur ulang sampah anorganik di bank sampah
Responden memiliki persepsi yang berbeda-beda terhadap pengelolaan sampah rumah tangga. Penjelasan secara terperinci mengenai persepsi responden terhadap pengelolaan sampah rumah tangga disajikan dalam Tabel 1.

Partisipasi Masyarakat dalam Pengelolaan Sampah Rumah Tangga

Partisipasi masyarakat dalam pengelolaan sampah rumah tangga merupakan keterlibatan individu dalam pengelolaan sampah rumah tangga, baik secara langsung maupun tidak langsung. Partisipasi secara langsung merupakan keikutsertaan individu dalam

kegiatan yang berhubungan langsung dengan sampah rumah tangga, di antaranya kegiatan-kegiatan yang berhubungan dengan prinsip 3R sebagai prinsip utama dalam pengelolaan sampah rumah tangga. Partisipasi secara tidak langsung dapat dilakukan dengan memberikan ide, gagasan, materi, serta dengan mengikuti sosialisasi dan pelatihan mengenai pengelolaan sampah rumah tangga.

Selain partisipasi secara langsung, partisipasi dalam pengelolaan sampah rumah tangga juga dapat dilakukan secara tidak langsung. Walaupun tidak bersentuhan langsung dengan sampah rumah tangga, partisipasi secara tidak langsung dapat membantu memperlancar proses pengelolaan sampah rumah tangga. Sebaran responden berdasarkan partisipasi dalam pengelolaan sampah rumah tangga secara tidak langsung Tabel 3. 
Tabel 1. Persepsi responden terhadap pengelolaan sampah rumah tangga

\begin{tabular}{|c|c|c|c|c|c|c|c|c|}
\hline \multirow{2}{*}{ Pernyataan/Persepsi } & \multicolumn{2}{|c|}{ Setuju } & \multicolumn{2}{|c|}{ Cukup Setuju } & \multicolumn{2}{|c|}{ Kurang Setuju } & \multicolumn{2}{|c|}{ Tidak Setuju } \\
\hline & $\mathrm{n}$ & $\%$ & $\mathrm{n}$ & $\%$ & $\mathrm{n}$ & $\%$ & $\mathrm{n}$ & $\%$ \\
\hline Sampah rumah tangga perlu dikelola setiap hari & 30 & 96.77 & 1 & 3.23 & 0 & 0 & 0 & 0 \\
\hline $\begin{array}{l}\text { Sampah rumah tangga yang dibiarkan menumpuk dapat } \\
\text { menimbulkan dampak buruk bagi lingkungan }\end{array}$ & 31 & 100 & 0 & 0 & 0 & 0 & 0 & 0 \\
\hline $\begin{array}{l}\text { Sampah organik dan sampah anorganik harus dipilah } \\
\text { sebelum dibuang ke tempat sampah }\end{array}$ & 31 & 100 & 0 & 0 & 0 & 0 & 0 & 0 \\
\hline $\begin{array}{l}\text { Pengelolaan sampah rumah tangga menjadi kompos } \\
\text { memberikan manfaat bagi Anda }\end{array}$ & 31 & 100 & 0 & 0 & 0 & 0 & 0 & 0 \\
\hline $\begin{array}{l}\text { Pemakaian plastik sebaiknya dikurangi karena plastik } \\
\text { sulit terurai secara alami }\end{array}$ & 31 & 100 & 0 & 0 & 0 & 0 & 0 & 0 \\
\hline $\begin{array}{l}\text { Sampah yang masih bisa dipakai sebaiknya dimanfaatkan } \\
\text { kembali }\end{array}$ & 31 & 100 & 0 & 0 & 0 & 0 & 0 & 0 \\
\hline $\begin{array}{l}\text { Pemindahan sampah ke tempat pembuangan sementara } \\
\text { penting dilakukan agar tidak terjadi penumpukan sampah } \\
\text { rumah tangga }\end{array}$ & 31 & 100 & 0 & 0 & 0 & 0 & 0 & 0 \\
\hline Pengelolaan sampah rumah tangga mudah dilakukan & 31 & 100 & 0 & 0 & 0 & 0 & 0 & 0 \\
\hline $\begin{array}{l}\text { Pengelolaan sampah dengan prinsip } 3 \mathrm{R} \text { merupakan cara } \\
\text { yang efisien dalam mengatasi masalah mengenai sampah } \\
\text { rumah tangga }\end{array}$ & 31 & 100 & 0 & 0 & 0 & 0 & 0 & 0 \\
\hline $\begin{array}{l}\text { Pembayaran biaya retribusi untuk fasilitas pengelolaan } \\
\text { sapah perlu dilakukan secara rutin }\end{array}$ & 30 & 96.77 & 1 & 3.23 & 0 & 0 & 0 & 0 \\
\hline
\end{tabular}

Tabel 2. Partisipasi masyarakat dalam pengelolaan sampah sampah rumah tangga secara langsung

\begin{tabular}{|c|c|c|c|c|c|c|c|c|}
\hline \multirow{2}{*}{ Pernyataan } & \multicolumn{2}{|c|}{ Sering } & \multicolumn{2}{|c|}{ Cukup sering } & \multicolumn{2}{|c|}{ Jarang } & \multicolumn{2}{|c|}{ Tidak Pernah } \\
\hline & $\mathrm{n}$ & $\%$ & $\mathrm{n}$ & $\%$ & $\mathrm{n}$ & $\%$ & $\mathrm{n}$ & $\%$ \\
\hline Memilah sampah organik dan anorganik & 30 & 96.77 & 1 & 3.23 & 0 & 0 & 0 & 0 \\
\hline Membawa wadah sendiri ketika berbelanja & 2 & 6.452 & 28 & 90.3 & 1 & 3.226 & 0 & 0 \\
\hline Menghemat penggunaan plastik & 27 & 87.1 & 4 & 12.9 & 0 & 0 & 0 & 0 \\
\hline Menggunakan kertas pada kedua sisinya & 27 & 87.1 & 4 & 12.9 & 0 & 0 & 0 & 0 \\
\hline Membawa sampah ke tempat pembuangan sementara & 27 & 87.1 & 4 & 12.9 & 0 & 0 & 0 & 0 \\
\hline Menabung sampah di bank sampah & 2 & 6.452 & 28 & 90.3 & 1 & 3.226 & 0 & 0 \\
\hline $\begin{array}{l}\text { Memanfaatkan kembali botol/kaleng yang masih dapat } \\
\text { digunakan }\end{array}$ & 1 & 3.226 & 30 & 96.8 & 0 & 0 & 0 & 0 \\
\hline Membuat kerajinan dari barang bekas & 0 & 0 & 29 & 93.5 & 2 & 6.452 & 0 & 0 \\
\hline Mendaur ulang sampah menjadi pupuk kompos & 28 & 90.32 & 3 & 9.68 & 0 & 0 & 0 & 0 \\
\hline Mengikuti kegiatan kebersihan seperti kerja bakti & 27 & 87.1 & 4 & 12.9 & 0 & 0 & 0 & 0 \\
\hline
\end{tabular}

Tabel 3. Partisipasi masyarakat dalam pengelolaan sampah sampah rumah tangga secara tidak langsung

\begin{tabular}{|c|c|c|c|c|c|c|c|c|}
\hline \multirow{2}{*}{ Pernyataan } & \multicolumn{2}{|c|}{ Sering } & \multicolumn{2}{|c|}{ Cukup sering } & \multicolumn{2}{|c|}{ Jarang } & \multicolumn{2}{|c|}{ Tidak Pernah } \\
\hline & $\mathrm{n}$ & $\%$ & $\mathrm{n}$ & $\%$ & $\mathrm{n}$ & $\%$ & $\mathrm{n}$ & $\%$ \\
\hline $\begin{array}{l}\text { Memberikan saran dan kritik mengenai pengelolaan sampah } \\
\text { rumah tangga kepada pengurus RT/RW }\end{array}$ & 0 & 0 & 3 & 9.68 & 27 & 87.1 & 1 & 3.2 \\
\hline $\begin{array}{l}\text { Mendiskusikan tentang pengelolaan sampah rumah tangga } \\
\text { bersama warga yang lainnya }\end{array}$ & 4 & 12.9 & 27 & 87.1 & 0 & 0 & 0 & 0 \\
\hline $\begin{array}{l}\text { Mengikuti penyuluhan atau sosialisasi mengenai pengelolaan } \\
\text { sampah rumah tangga }\end{array}$ & 27 & 87.1 & 3 & 9.68 & 1 & 3.226 & 0 & 0 \\
\hline $\begin{array}{l}\text { Mengikuti pelatihan mengenai pengelolaan sampah rumah } \\
\text { tangga }\end{array}$ & 27 & 87.1 & 3 & 9.68 & 1 & 3.226 & 0 & 0 \\
\hline $\begin{array}{l}\text { Membayar biaya retribusi untuk meningkatkan fasilitas } \\
\text { pengelolaan sampah }\end{array}$ & 29 & 93.55 & 2 & 6.45 & 0 & 0 & 0 & 0 \\
\hline
\end{tabular}

Partisipasi masyarakat dalam pengelolaan sampah rumah tangga dalam penelitian ini memiliki 2 kategori, yaitu rendah dan tinggi. Klasifikasi pada kategori tersebut didasari oleh hasil akumulasi dari partisipasi masyarakat secara langsung dan tidak langsung yang telah dipaparkan di atas. Sebaran responden berdasarkan partisipasi dalam pengelolaan sampah rumah tangga disajikan dalam Tabel 4. 
Tabel 4. Sebaran responden berdasarkan partisipasi dalam pengelolaan sampah rumah tangga

\begin{tabular}{|c|c|c|c|c|}
\hline Partisipasi & Jumlah & Persentase (\%) & Mean & Standar Deviasi \\
\hline Rendah(skor 8-17) & 0 & 0 & \multirow{2}{*}{40.5751} & \multirow{2}{*}{4.486441} \\
\hline Tinggi(skor 19-41) & 31 & 100 & & \\
\hline Total & 31 & & & \\
\hline
\end{tabular}

Tabel 4 menunjukkan bahwa 100 persen responden memiliki tingkat partisipasi yang tinggi dalam pengelolaan sampah rumah tangga. Hasil ini menunjukkan bahwa mayoritas responden sudah berpartisipasi secara langsung dan tidak langsung dalam pengelolaan sampah rumah tangga.

Hal ini sesuai dengan keadaan di lapangan, nasabah Bank Sampah Rawajati aktif berpartisipasi dalam pengelolaan sampah rumah tangga. Prinsip 3R telah diterapkan pada kehidupan sehari-hari masyarakat. Pengelolaan sampah basah yang dilakukan setiap hari dan penimbangan sampah kering yang dilakukan setiap dua minggu sekali merupakan partisipasi nyata yang telah dijalankan secara berkelanjutan oleh nasabah Bank Sampah Rawajati.

Menurut Astuti (2011), partisipasi akan muncul ketika masyarakat mulai sadar akan masalah yang dihadapi dan mampu mengidentifikasi kebutuhan mereka. Kesadaran yang sudah tumbuh pada nasabah Bank Sampah Rawajati membuat mereka memiliki kemauan untuk turut berpartisipasi dalam pengelolaan sampah rumah tangga. Banyak manfaat yang telah dirasakan masyarakat, seperti manfaat secara sosial dan ekonomi. RW 03 Kelurahan Rawajati sering mendapat kunjungan dari berbagai instansi pemerintah, swasta, perguruan tinggi, dan masyarakat dari daerah lain berkat adanya Bank Sampah Rawajati. Kunjungankunjungan tersebut merupakan kebanggaan dan motivasi tersendiri.

\subsection{Hubungan Antara Persepsi dan Partisipasi Masyarakat dalam Pengelolaan Sampah Rumah Tangga}

Secara keseluruhan, nasabah Bank Sampah Rawajati ternyata memiliki persepsi yang positif terhadap pengelolaan sampah rumah tangga. Warga menilai bahwa pengelolaan sampah rumah tangga dapat merupakan hal yang penting dilakukan dan dapat mendatangkan manfaat. Persepsi terhadap pengelolaan sampah rumah tangga yang terbentuk pada nasabah Bank Sampah Rawajati sudah baik. Persepsi yang positif ini terbentuk terutama disebabkan oleh lingkungan tempat tinggal yang kondusif untuk melaksanakan pengelolaan sampah rumah tangga. Keberadaan Bank sampah Rawajati yang terletak dekat dengan tempat tinggal membuat warga memandang bahwa sampah yang terlihat sebagai barang yang sudah tidak berguna sebenarnya dapat dimanfaatkan kembali menjadi sesuatu yang bernilai. Selain itu, adanya peran tokoh masyarakat yang tinggi dan sarana dan prasarana yang memadai merupakan keunggulan daerah ini sehingga membuat masyarakat memiliki persepsi yang baik terhadap pengelolaan sampah rumah tangga.
Menurut penelitian ini, yang terjadi pada nasabah Bank Sampah Rawajati adalah mereka memiliki persepsi positif terhadap pengelolaan sampah rumah tangga cenderung memiliki tingkat partisipasi yang tinggi dalam pengelolaan sampah rumah tangga (Tabel 5). Hal ini sejalan dengan penelitian yang telah dilakukan oleh Manurung (2008), persepsi seseorang terhadap pengelolaan sampah mempengaruhi partisipasinya dalam pengelolaan sampah.

Tabel 5. Korelasi antara persepsi dan partisipasi masyarakat dalam pengelolaan sampah rumah tangga

\begin{tabular}{cccc}
\hline $\begin{array}{c}\text { Variabel } \\
\text { Independen }\end{array}$ & $\mathrm{r}$ & $\mathrm{p}$ & Keterangan \\
\hline PARTISIPASI & 0.382 & 0.034 & Berkorelasi \\
\hline
\end{tabular}

Berdasarkan Tabel 5, terlihat bahwa terdapat hubungan yang signifikan antara persepsi dan partisipasi masyarakat dalam pengelolaan sampah rumah tangga. Hasil olah data dengan SPSS menunjukkan nilai koefisien korelasi linier (r) antara persepsi terhadap partisipasi adalah 0.382. Hal ini berarti terdapat hubungan linier yang sangat kuat dan positif antara persepsi dan partisipasi dalam pengelolaan sampah rumah tangga. Artinya, semakin baik persepsi masyarakat terhadap pengelolaan sampah rumah tangga, maka akan semakin tinggi tingkat partisipasi masyarakat dalam pengelolaan sampah rumah tangga, begitu juga sebaliknya, semakin negatif persepsi seseorang terhadap pengelolaan sampah rumah tangga, maka akan semakin rendah partisipasinya dalam pengelolaan sampah rumah tangga. Nilai $p(0.034)<\alpha(0.05)$ memiliki arti bahwa hipotesis penelitian ini yang menduga bahwa terdapat hubungan nyata antara persepsi masyarakat terhadap pengelelolaan sampah rumah tangga dengan partisipasi masyarakat dalam pengelolaan sampah rumah tangga dapat diterima.

Hasil penelitian ini sejalan dengan hasil penelitian Juarsyah (2007) yang menjelaskan bahwa partisipasi yang dilakukan seseorang dilandasi oleh persepsi, dan persepsi memiliki hubungan yang signifikan dengan partisipasi. Selain itu, Notoatmodjo (2003) menjelaskan bahwa suatu tindakan yang dilakukan seseorang tidak akan langsung terwujud karena diperlukan faktor pendukung atau kondisi yang memungkinkan untuk terwujudnya suatu tindakan. Persepsi merupakan faktor pendukung terwujudnya tindakan tersebut sehingga berhubungan erat dengan tindakan seseorang. Nasabah Bank Sampah Rawajati memiliki persepsi yang positif serta lingkungan kondusif untuk melaksanakan pengelolaan sampah 
rumah tangga sebagai faktor pendukung terwujudnya partisipasi. Faktor tersebut yang mendorong para warga untuk turut berpartisipasi dalam pengelolaan sampah rumah tangga.

\subsection{Hubungan Antara Faktor Internal dan Eksternal Individu dengan Persepsi Terhadap Pengelolaan Sampah Rumah Tangga}

Berdasarkan uji korelasi Rank Spearman, diketahui bahwa ternyata hanya beberapa dari faktor internal individu, yaitu pengetahuan dan pengalaman yang berhubungan nyata dengan persepsi terhadap pengelolaan sampah rumah tangga. Hasil uji korelasi antara faktor internal dan eksternal individu dengan persepsi terhadap pengelolaan sampah rumah tangga dapat dilihat pada Tabel 6 .

Menurut pendapat yang dikemukakan oleh Sarwono (1999), persepsi seseorang dipengaruhi oleh faktor internal dan eksternal. Pendapat yang sama juga dikemukakan oleh Thoha (1999) yang menjelaskan bahwa persepsi pada umumnya dipengaruhi oleh faktor yang berasal dari dalam diri individu dan dari luar individu atau lingkungannya. Sejalan dengan pendapat tersebut, hasil penelitian ini menunjukkan bahwa faktor internal dan eksternal individu memiliki hubungan dengan persepsi masyarakat terhadap pengelolaan sampah.

Tabel 6. Hasil uji korelasi antara faktor internal dan ekternal individu dengan persepsi terhadap pengelolaan sampah rumah tangga

\begin{tabular}{|c|c|c|c|c|}
\hline \multicolumn{2}{|c|}{ Variabel Independen } & $\mathrm{r}$ & $\mathrm{p}$ & \multirow{2}{*}{$\begin{array}{c}\text { Keterangan } \\
\text { Tidak Berkorelasi }\end{array}$} \\
\hline Faktor Internal Individu & Usia & 0.082 & 0.662 & \\
\hline & Jenis Kelamin & -0.155 & 0.405 & Tidak Berkorelasi \\
\hline & Pendidikan & -0.215 & 0.246 & Tidak Berkorelasi \\
\hline & Pekerjaan & -0.099 & 0.598 & Tidak Berkorelasi \\
\hline & Pendapatan & -0.166 & 0.373 & Tidak Berkorelasi \\
\hline & Pengetahuan & $0.695 * *$ & $0.000 * *$ & Berkorelasi \\
\hline & Pengalaman & $0.719 * *$ & $0.000 * *$ & Berkorelasi \\
\hline \multirow{2}{*}{$\begin{array}{l}\text { Faktor Eksternal } \\
\text { Individu }\end{array}$} & Peran Pemerintah & $0.695^{* *}$ & $0.000 * *$ & Berkorelasi \\
\hline & Sarana Prasarana & $-0.474 * *$ & $0.007 * *$ & Berkorelasi \\
\hline
\end{tabular}

Keterangan: **berhubungan nyata pada $\mathrm{p}<0.05$

\section{Kesimpulan}

Berdasarkan hasil penelitian, dapat ditarik kesimpulan bahwa nasabah Bank Sampah Rawajati menilai pengelolaan sampah harus dilakukan secara berkesinambungan, 96.77 persen setuju bahwa sampah harus dikelola setiap hari. Sebanyak seluruh responden juga setuju bahwa sampah yang menumpuk berdampak buruk pada lingkungan. Seluruh responden setuju bahwa sampah rumah tangga harus dipilah sebelum dibuang ke tempat sampah. Sampah yang telah dipilah akan memudahkan proses pengelolaan sampah yang selanjutnya.

Partisipasi masyarakat dalam pengelolaan sampah di Bank Sampah Rawajati merupakan keterlibatan masyarakat secara langsung maupun tidak langsung dalam upaya mengelola sampah menjadi suatu benda lain yang memilki manfaat. Partisipasi merupakan modal yang penting bagi program pengelolaan sampah untuk dapat berhasil mengatasi permasalahan mengenai sampah rumah tangga yang banyak terdapat di lingkungan masyarakat, terutama di perkotaan.

Persepsi nasabah Bank Sampah Rawajati terhadap pengelolaan sampah rumah tangga secara keseluruhan adalah positif dan partisipasi masyarakat dalam pengelolaan sampah rumah tangga secara keseluruhan sudah tinggi.

Secara keseluruhan, nasabah Bank Sampah Rawajati ternyata memiliki persepsi positif terhadap 3R atau mendukung penanganan sampah yang berwawasan lingkungan. Semakin baik persepsi masyarakat terhadap pengelolaan sampah rumah tangga, maka akan semakin tinggi tingkat partisipasi masyarakat dalam pengelolaan sampah rumah tangga, begitu juga sebaliknya, semakin negatif persepsi seseorang terhadap pengelolaan sampah rumah tangga, maka akan semakin rendah partisipasinya dalam pengelolaan sampah rumah tangga.

\section{Ucapan Terima Kasih}

Penulis mengucapkan terimakasih kepada Kementerian Lingkungan Hidup dan Kehutanan untuk dukungan fasilitas dan dana penelitian ini.

\section{Daftar Pustaka}

[1] Alfiandra, 2009. Kajian partisipasi masyarakat yang melakukan pengelolaan persampahan 3R di Kelurahan Ngaliyan dan Kalipancur Kota Semarang, Tesis, Universitas Diponegoro, Semarang. [terhubung berkala]. http://eprints.undip.ac.id/ 24266 / 1 / ALFIANDRA .pdf. [9 November 2013].

[2] Astuti Y.P., 2011. Partisipasi peserta dalam program pengelolaan sampah organik di komunitas kumuh perkotaan bantaran Sungai Ciliwung. Bogor, Institut Pertanian Bogor.

[3] Candra I., 2012. Partisipasi masyarakat dalam pengelolaan sampah rumah tangga (Studi kasus di Kelurahan Siantan Tengah Kecamatan Pontianak Utara), Sociodev-Jurnal Ilmu Sosiatri. 1(1):1-21. [terhubung berkala]. http://jurnalmahasiswa.fisip. untan.ac.id /index.php/jurnalsosiatri/article/view/ 140. [9 Oktober 2013].

[4] Dortmans B., 2015. Valorisation of organic waste-Effect of the feeding regime on process parameters in a continuous black soldier fly larvae composting system. Theses. Department of Energy and Technology, Swedish University of Agricultural Sciences, Swedish. 
[5] Juarsyah R., 2007. Persepsi dan partisipasi peternakan tentang program perguliran ternak domba (Kasus kelompok tani mandiri, Desa Laladon, Kecamatan Ciomas, Kabupaten Bogor). Bogor, Institut Pertanian Bogor. [terhubung berkala]. http://repository.ipb.ac.id/xmlui/bitstream/handle/ 123456789/31991/D07rju.pdf. [1 Mei 2014].

[6] [KLHK] Kementerian Lingkungan Hidup dan Kehutanan, 2015. Rangkaian hari lingkungan hidup 2015-dialog penanganan sampah plastik [terhubung berkala]. http://www.menlh.go.id. [6 November 2015].

[7] Koentjaraningrat, 1991. Metode-Metode Penelitian Masyarakat. Jakarta, Gramedia.

[8] Manurung R., 2008. Persepsi dan partisipasi siswa sekolah dasar dalam pengelolaan sampah di lingkungan sekolah. Jurnal Pendidikan Penabur. 1(10):22-34. [terhubung berkala]. http:// www.bpkpenabur.or.id/files/Hal.\%2022-34\%20 Persepsi\%20 dan $\% 20$ partisifasi \% 20 siswa . pdf. [20 Oktober 2013]

[9] Notoatmodjo S., 2003. Pendidikan dan Perilaku Kesehatan. Jakarta, PT Rineka Cipta.
[10] Simamora, S., Salundik, S. Wahyuni, dan Surajudin, 2006. Membuat biogas pengganti bahan bakar minyak dari kotoran ternak. Agromedia Pustaka, Jakarta.

[11] Sugihartono, Fathiyah KN, Harahap F, Setiawati FA, Nurhayati SR. 2007. Psikologi Pendidikan. Yogyakarta, UNY Press.

[12] Suyanto, E., E. Soetarto, Sumardjo, dan H. Hardjomidjojo, 2015. Model kebijakan pengelolaan sampah berbasis partisipasi "Green Community" mendukung kota hijau. Mimbar 31(1), pp. 143-152.

[13] Thoha M., 1999. Perilaku Organisasi. Bandung, Roksadaya.

[14] Yolarita E., 2011. Pengelolaan sampah dengan prinsip 3R di Kota Solok. Tesis. Universitas Padjajaran, Bandung. [terhubung berkala]. http://pustaka.unpad.ac.id/archives/119693. [2 November 2013].

[15] Yuliastuti I.A.N., I.N.M. Yasa, I.M. Jember, 2013. Partisipasi masyarakat dalam pengelolaan sampah di Kabupaten Badung. Jurnal Ekonomi dan Bisnis Universitas Udayana. 2(6):374$393 . \quad$ [terhubung berkala]. http://ojs.unud.ac.id/index.php/EEB/article/download/5380/ 4152. [16 Oktober 2013] 